\title{
The Relationship Between Secondary School Teachers' Perception of Organizational Justice and School Climate
}

\author{
Mustafa KEMER* \\ Institute of Education Sciences, Kocaeli University, Kocaeli, Turkey \\ ORCID: 0000-0001-5750-1461 \\ Soner POLAT \\ Faculty of Education, Kocaeli University, Kocaeli, Turkey \\ ORCID: 0000-0003-2407-6491
}

Article history

Received:

11.05.2021

Received in revised form: 17.11.2021

Accepted:

12.12.2021

Key words:

Organizational justice;

School climate;

Secondary school
In this research, it is aimed to reveal the relationship between secondary school teachers' perception of organizational justice and their perception of school climate. The research is a relational descriptive study in which the survey model is used. The sample of the study consists of 370 teachers selected by convenient sampling method among the teachers working in the general and imam hatip secondary schools in Izmit district of Kocaeli province in the academic year 2020-2021. "Organizational Justice Scale" and "Organizational Climate Scale" were used as data collection tools. In the analysis of the data, Pearson correlation coefficient was calculated for the relationship between variables, and simple linear regression analysis and multiple linear regression analysis were performed for predictive variables. As a result of the study, it was determined that there is a positive, moderately significant relationship between organizational justice and school climate. It was found that teachers' perceptions of organizational justice are a significant predictor of school climate, and the order of importance of the sub-dimensions of organizational justice in explaining school climate is "procedural justice", "distributive justice", and "interactional justice". In addition, the research findings show that organizational justice affects the supportive principal behavior, which is one of the sub-dimensions of the school climate, the most.

\section{Introduction}

It is an undeniable fact that educational organizations are important in achieving goals such as making societies qualified, raising qualified individuals, transferring universal knowledge and values to future generations, and making individuals and societies a part of the rapidly changing and developing world. In this context, schools, which are one of the educational organizations, have been the focus of attention of researchers on many issues due to their social open system.

\footnotetext{
*Correspondency: mstfkmr@gmail.com
} 
Each of the schools that aim to achieve the determined goals in the best way has its own characteristics and climate (Hoy \& Miskel, 2010; Welsh, 2000). The climate in the school can affect the teachers, who are among the important and effective stakeholders of the school, positively or negatively. Therefore, school administrators who want to achieve their goals should have a management approach to create a positive climate in their schools. In a school with a positive climate, teachers love their jobs, their students, establish good relations with their colleagues, and are happy to work at the school they are in. They show all their performances in order to achieve the determined goals. Learning environments are prepared according to the needs of the students. Students study well and respect each other. School administrators constantly support teachers, approach them friendly and provide the necessary resources for the school (Sweetland \& Hoy, 2000). According to Greenberg (1990), knowing how the decisions taken by the managers in the organization and the practices carried out are perceived by the employees and their correct understanding by the employees are great importance in terms of creating a fair organizational climate.

The concept of justice, which is almost as old and an important concept as human history, affects social life as well as organizational life. In this context, it is thought that organizational justice will have an important effect on shaping the climate of school organizations. The concept of justice, which has an important place in the healthy maintenance and regulation of social life, is expected to manifest itself in educational organizations, which are open social systems. School administrators' fair attitude and behavior in decision-making processes and using the resources of the school will create a sense of trust in teachers and increase teachers' commitment to the school. Otherwise, the performance of teachers will decrease and their motivation and confidence in their schools will decrease. Therefore, it can be said that the concept of organizational justice has an important place in educational organizations in terms of the relationship and power of interaction between administrators, teachers and students (Cansoy \& Polatcan, 2018). For this reason, the concept of organizational justice, which is considered to be an important factor on the school climate, needs to be investigated and defined in terms of educational organizations. This study focuses on the relationship between teachers' perception levels of organizational justice and its sub-dimensions and school climate perception levels.

\section{Literature Review}

Justice, in essence, has the ability to keep people together in social life, to keep them in peace and to keep people with different characteristics together (Greenberg, 2003). Associating the concept of justice with order, Welch emphasized the importance of justice in establishing order and resolving conflicts that arise in society and stated that it would be very difficult to maintain and maintain order without justice (Bal, 2001). In the Dictionary of Educational Administration and Supervision, prepared by Demirtaş and Güneş (2002), the concept of justice is expressed as giving the rights of employees in proportion to the value they add to the organization, and punishment for not obeying the rules of the organization.

It is thought that the concept of organizational justice emerged, became conceptual and its use became widespread with the study of Greenberg in 1987 (Altınkurt \& Y1lmaz, 2010). Organizational justice is the thoughts that organization members have about being treated fairly (Cohen-Charash \& Spector, 2001; Greenberg, 1987). The foundation of the concept of organizational justice is based on the "Equality Theory" put forward by Adams (1965). According to Adams' Equality Theory, employees compare the gains they have gained in their organizations in return for the effort they spend with those who work in their own 
organizations as well as those who spend similar efforts in other organizations. According to the perception formed as a result of this comparison, the individual develops attitudes and behaviors related to the organization, principal and job (Greenberg, 1996).

Organization employees can be affected by practices such as, starting from the way they are recruited in the organization, performance evaluations, remuneration, authorization, rewarding, changes in their status, and their approach to decision-making processes. Employees form some behavioral patterns according to their perceptions on issues such as whether the principals treat them fairly, whether the awards are distributed fairly, and how fair the wages are (Irak, 2004; İçerli, 2010). It is stated that if the perception of organizational justice is negative, there may be consequences such as boredom, dissatisfaction, resentment, low motivation, conflict and weak interaction, and if organizational justice is perceived positively by employees, consequences such as high motivation, job satisfaction, respectability, trust in the organization and the principal, strong interaction, belonging to the organization, citizenship and a positive organizational climate may be experienced (Beugre, 1998).

While some researchers argue that organizational justice consists of two dimensions, distributive justice and procedural justice (İşcan \& Naktiyok, 2004; Moorman, 1991), some researchers included the dimension of interactional justice as the third dimension (Aquino, 1995; Barling and Phillips, 1993; Greenberg, 1990). The generally accepted view in the related literature is that organizational justice has three dimensions: "distributive justice", "procedural justice", and "interactional justice" (Demirel \& Seçkin, 2011).

For distributive justice, which is the first sub-dimension of organizational justice, it can be said that it is about sharing and distributing outputs. In this dimension, there is a perception of justice regarding the gains of employees from their organizations (Özkalp \& Kırel, 2013). In educational organizations, whether school administrators behave fairly or not in terms of teachers' descriptions of their duties and distribution of courses and additional courses affects teachers' perceptions of distributive justice towards their schools. Although school administrators are not authorized in determining the wages of teachers, they have an important role in the fair distribution of the course and additional course distribution (Açıkgöz, 2009).

Procedural justice is the perception of justice regarding the preferred methods of distributing gains, in short, the process (Irak, 2004). In other words, organization employees are not only interested in the distribution of inputs and outputs, but also want to know the criteria by which this distribution is made (Usmani \& Jamal, 2013). Therefore, it can be said that procedural justice tries to make up for the missing part of distributive justice. In educational organizations, including teachers in the decision-making processes, especially in matters directly related to teachers, asking their opinions, having the right to speak strengthens the belief that the process is fair in educational organizations (Hoy \& Tarter, 2004).

Cropanzano et al. (2007) associate interactional justice with the way two individuals behave each other. They state that interactional justice has two sub-dimensions: "informational justice" and "interpersonal justice". For "informational justice", it can be said that the employees in the organization are given information about the sharing of gains and the process of this sharing. For "interpersonal justice", it can be said that it is related to the degree of kindness, respect and value of the communication and relationship between the members of the organization. In educational organizations, when school administrators' approaches to 
teachers are polite, respectful, and consistent, and an appropriate language is used to announce some decisions, this contributes to positive interaction between teachers and school administrators (Hoy \& Tarter, 2004).

The positive perception of justice in organizations also affects many outcomes such as organizational happiness (Çetin \& Polat, 2021), professional commitment (Alazmi \& Alenezi, 2020), organizational citizenship (Raj et al., 2016), organizational identification (Cüce et al., 2013), job satisfaction (Yürür, 2008), organizational trust (Polat, 2007), and school climate (Dipaola \& Guy, 2009). It is known that the school climate, which is one of these outputs, affects the quality of education, teacher performance (Katsantonis, 2020), and accordingly student achievement, teacher and student productivity.

It can be said that many different definitions have been made by researchers in the literature on organizational climate. According to Litwin and Stringer (1968), the organizational climate is the measurable aspect of the organization, which consists of the perceptions of the employees who are in interaction and influences their behavior (cited in Hoy and Miskel, 2010). In other words, employees' perceptions of rewarding, sincerity, kindness and support towards the psychological structure of their organizations are expressed as organizational climate (Tutar \& Altınöz, 2010). Based on this, the psychological environment of the organization can be called the organizational climate.

The organizational climate can be described as the atmosphere felt when entering the organization. The way employees perceive the practices in the organization, the way these practices are made, the behaviors of the principals, how the remuneration is made, what is accepted and what is not, reflect the climate in that organization (Balc1, 2001).

When the literature on organizational climate types is examined, it can be seen that the researchers examine the organizational climate in different types. According to Halpin and Croft (1963), one of the leading researchers on the subject, the organizational climate is of six types: "open climate", "autonomous climate", "controlled climate", "familiar climate", "paternal climate" and "closed climate".

In the study conducted by Hoy, Tarter \& Kottkamp (1991) on educational organizations, the organizational climate was examined in six dimensions. Among these dimensions, supportive principal, peremptory principal, and restrictive principal dimensions are related to the behaviors of the school principal, while the collaborative teacher, sincere teacher, and reckless teacher dimensions are also related to teacher behaviors. In the supportive principal dimension, there is a balanced relationship between school administrators and teachers. The school administrator listens to the teachers' suggestions and praises them frequently and sincerely. The school administrator's criticisms are constructive. In the peremptory principal's dimension, the school principal's attitude is strict. The school administrator supervises the teachers frequently and follows everything done in the school down to the smallest detail. In the dimension of restrictive principal, the school administrator makes the tasks that need to be done more difficult by placing a lot of workload on teachers instead of making their jobs easier. In the collaborative teacher dimension, which is related to teacher behaviors, teachers help each other and support each other professionally. Teachers are happy with their colleagues and working at that school. At the dimension of sincere teachers, teachers know each other well and make sincere friendships. They often come together and participate in social activities together. In the last dimension, the reckless teacher dimension, teachers are purposeless, and they are in school to fill their time. Their behavior is generally negative. 
They constantly criticize other teacher friends. Relationships within the school are mostly between small groups, but they are inefficient.

In order for the education offered to individuals to be of high quality, the school climate must also be healthy. Creating the educational environment in a way that makes learning and teaching willing will ensure that the school is also effective (Şişman, 2011). School climate can be said to be an effective tool for schools to become more efficient (Hoy et al., 1991). This situation can be expressed as schools with a positive school climate can be more effective and efficient.

The inclusion of teachers in the decision-making processes in educational organizations is effective in the formation of the perception of justice in teachers towards their organizations. In this sense, the school administrator should be sincere. Because although the school administrator makes the decisions himself, when he acts as if he is including the teachers in this process, when he trusts only the teachers who are close to him, other teachers will feel worthless, and they will have the perception that their expectations cannot be met by the school administration (Demirbolat, 1999). In other words, the inclusion of teachers in the process of making decisions about them will result in a positive perception of justice (Hoy \& Tarter, 2004). It can be stated that the concept of organizational justice sometimes directly and sometimes indirectly affects the climate in organizations, because the concept of organizational climate is related to how organization members perceive their organization as a result of the communication and interaction between the organization's management approach and organization members (Yahyagil, 2006).

The concept of organizational justice has a critical importance for leadership studies, compliance with organizational climate, and the morale - motivation and performance of organization employees. In this context, Huang et al. (2019) revealed in their research on the effects of organizational justice on organizational climate and organizational performance that there is a positive relationship between organizational justice and organizational climate and organizational performance. In other words, as a result of the increase in the perceived justice in the organization, the climate is positively affected by this situation and the performance of the employees increases (Huang et al., 2019).

In order to see the effects of organizational justice in educational organizations, Dipaola and Guy (2009) investigated "the impact of organizational justice on climate and trust in high schools". As a result of the research, it has been observed that there is a positive significant relationship between organizational justice and school climate. In this context, it can be said that school administrators' being fair in their decisions and practices is effective in shaping the school climate (Dipaola \& Guy, 2009).

It can be said that teachers' perceptions of justice towards their schools are effective on the school climate as it will also reflect on the communication and interaction within the school. A study conducted in Indonesia supports this situation. Research results show the effect of teachers' perceptions of justice on the school climate. That is, the fairer teachers are treated, the better this will have an impact on the school climate. Therefore, it can be said that perceived justice has a direct effect on the organizational climate (Achmadi, 2016). This result also supports the results of the research conducted by Cohen and Keren (2010) at the high school level in Israel.

This study is important in terms of focusing on the relationship between organizational justice 
and school climate and examining the dimensions of organizational justice that affect school climate and its sub-dimensions. It is thought that researchers who may work in this field in the future can benefit from the findings of the research in order to correctly base the possible relationship between organizational justice and school climate. At the same time, it is thought that the relationship between justice and climate, which are important concepts for organizations, can bring different perspectives to both organizations and managers. The aim of this study is to reveal the relationship between teachers' perception of organizational justice and their perception of school climate. For this aim, by measuring teachers' perceptions of justice and school climate levels; By describing the concepts of organizational justice and school climate in terms of some personal and organizational variables, it is aimed to reveal the relationship between the two.

\section{Methodology}

\section{Research Model}

In this study, it was tried to reveal the relationship between the perception levels of organizational justice of teachers working in secondary schools and their perception levels towards school climate. Therefore, the research is a study in relational (correlational) survey model, one of the quantitative research methods. In studies conducted in the relational (correlational) survey model, it is tried to explain the relationship of at least two quantitative variables with each other (Fraenkel et al., 2012).

\section{Population and Sample}

This research was conducted on teachers working in secondary schools in Turkey. In Turkish education system, secondary education is divided in two different school types, religious school and secondary school. Children between 10 and 14-years old take part in secondary education in Turkey. The General Directorate of Basic Education is responsible for the secondary school education while the General Directorate of Religious Education is responsible for the actions of religious secondary schools in Turkish education system.

1346 teachers working in 6 Imam Hatip Secondary Schools and 36 general secondary schools in Izmit, the central district of Kocaeli province, in the 2020-2021 academic year constitute the population of the study. Convenient sampling method was used in the sample selection of the study. Convenient sampling method is to select the sample from areas where it is more accessible and the application is feasible, if time, financial power, and conditions are limited (Büyüköztürk, 2014).

According to Yazıcioğlu and Erdoğan's (2004) sample calculation method, for cases where the size of the population is between 1000 and 2500, the sample size is thought to be enough between 278 and 333 people. The sample of this research is 370 people.

The demographic characteristics of the teachers who participated in the study are presented in Table 1 . 
Table 1. Demographic Characteristics of the Sample Group

\begin{tabular}{|c|c|c|c|}
\hline Variables & & $\mathbf{f}$ & $\%$ \\
\hline \multirow{3}{*}{ Gender } & Female & 243 & 65,7 \\
\hline & Male & 127 & 34,3 \\
\hline & Total & 370 & 100 \\
\hline \multirow{3}{*}{ Educational Status } & Bachelor's Degree & 322 & 87,0 \\
\hline & Master's Degree & 48 & 13,0 \\
\hline & Total & 370 & 100 \\
\hline \multirow{3}{*}{ School Type } & Normal Secondary School & 331 & 89,5 \\
\hline & Imam Hatip Secondary School & 39 & 10,5 \\
\hline & Total & 370 & 100 \\
\hline \multirow{4}{*}{ Age } & $20-30$ & 65 & 17,6 \\
\hline & $31-40$ & 167 & 45,1 \\
\hline & 41 and over & 138 & 37,3 \\
\hline & Total & 370 & 100 \\
\hline \multirow{3}{*}{$\begin{array}{l}\text { Being from the Same } \\
\text { Union }\end{array}$} & Yes & 109 & 29,5 \\
\hline & No & 261 & 70,5 \\
\hline & Total & 370 & 100 \\
\hline \multirow{6}{*}{ Professional Seniority } & $0-5$ Years & 34 & 9,2 \\
\hline & $6-10$ Years & 96 & 25,9 \\
\hline & $11-15$ Years & 83 & 22,4 \\
\hline & $16-20$ Years & 82 & 22,2 \\
\hline & 21 Years and over & 75 & 20,3 \\
\hline & Total & 370 & 100 \\
\hline
\end{tabular}

As can be understood from Table 1, 65.7\% (243) of the teachers participating in the study are female and $34.3 \%$ (127) are male. According to the educational status variable, $87 \%$ (322) of the participants have a bachelor's degree, while 13\% (48) have a master's degree. While $89.5 \%$ (331) of the participants work in the normal secondary school, $10.5 \%$ (39) of them work in the imam hatip secondary school. $17.6 \%$ (65) of the participants are between 20 and 30 years old, $45.1 \%$ (167) are between 31 and 40 years old, and 37.3\% (138) are aged 41 years or older. While the rate of participants who are from the same union as the school administrator is $29.5 \%$ (109), the rate of participants who answered no to this question is $70.5 \%$ (261). In terms of teachers' professional seniority variable, the rate of teachers with 0 5 years of professional seniority is $9.2 \%$ (34), the rate of teachers with 6-10 years of professional seniority is $25.9 \%$ (96), the rate of teachers with 11-15 years of professional seniority is $22.4 \%$ (83), the rate of teachers with professional seniority of $16-20$ years is $22.2 \%$ (82) and finally, the rate of teachers with professional seniority over 21 years is $20.3 \%$ (75).

\section{Data Collection Tools}

In the study, the "Organizational Justice Scale" was used to measure teachers' perception levels of organizational justice, and the "Organizational Climate Scale" was used to measure teachers' perception levels of school climate. 


\section{Organizational Justice Scale (OJS)}

OJS was developed by Niehoff and Moorman (1993) to measure teachers' perceptions of organizational justice towards their schools. This scale has been adapted to Turkish by Polat (2007). In the Likert type data collection tool, the items were graded with 5 intervals between "(1) Strongly Disagree, and (5) Strongly Agree". The scale consists of 19 items and 3 dimensions. Of these 19 items, 6 are about "distributive justice", 9 are about "procedural justice", and 4 are about "interactional justice" sub-dimensions. Polat (2007) found the Cronbach's Alpha reliability coefficient $\alpha=.96$ for the entire scale, and the Cronbach's Alpha reliability coefficient for the sub-dimensions of organizational justice was calculated as $\alpha=.89$ for distributive justice, $\alpha=.95$ for procedural justice, and $\alpha=.90$ for interactional justice. In this study, the Cronbach's Alpha reliability coefficient for the entire scale was found $\alpha=.97$ and the Cronbach's Alpha reliability coefficient for the sub-dimensions of organizational justice was calculated as $\alpha=.89$ for distributive justice, $\alpha=.92$ for procedural justice, and $\alpha=.85$ for interactional justice. According to Büyüköztürk (2014), the internal consistency coefficients being greater than .70 indicate that the reliability of the scale is high. Calculated internal consistency coefficients show that the reliability of the scale is high.

\section{Organizational Climate Scale (OCS)}

The "Organizational Climate Scale", developed by Hoy et al. (1991), finalized with the contributions of Hoy and Tarter (1997) and adapted to Turkish by Yilmaz and Altınkurt (2013). In the Likert type data collection tool, the items were graded with 4 intervals between "(1) Rarely Occurs, and (4) Very Frequently Occurs". The scale consists of 6 dimensions and 39 items. 9 of these items are related to the supportive principal, 7 to the peremptory principal, 5 to the restrictive principal, 7 to the sincere teacher, 7 to the collaborative teacher, and 4 to the reckless teacher. As a result of the Cronbach's Alpha test method used by Yilmaz and Altınkurt (2013) to determine reliability in terms of internal consistency, it was found to be .89 for the supportive principal behavior sub-dimension, .78 for the peremptory principal behavior sub-dimension, .73 for the restrictive principal behavior sub-dimension, .82 for the sincere teacher behavior sub-dimension, .80 for the collaborative teacher behavior subdimension and .70 for the reckless teacher behavior sub-dimension. In this study, the Cronbach's Alpha reliability coefficient for the entire scale was found $\alpha=.84$ and the Cronbach's Alpha reliability coefficient for the sub-dimensions of organizational climate was calculated as $\alpha=.93$ for the supportive principal behavior, $\alpha=.85$ for the peremptory principal behavior, $\alpha=.70$ for the restrictive principal behavior, $\alpha=.90$ for the sincere teacher behavior, $\alpha=.81$ for the collaborative teacher behavior and $\alpha=.75$ for the reckless teacher behavior. Calculated internal consistency coefficients show that the reliability of the scale is high.

\section{Data Collection and Analysis}

Firstly, research ethics committee approval and official permission from the provincial directorate of national education were obtained in order to apply the scales. After the researchers introduced themselves and briefly talked about the main lines of the research, they gave the scales to 410 teachers who wanted to participate in the research on a voluntary basis, and the scales filled in by the teachers were collected by the researchers to be used in the study. After collecting 410 data, 40 scales that were incomplete, incorrectly filled or not filled in at all were removed, and the data of the remaining 370 scales were processed into the SPSS program for analysis.

In order to understand whether the variables are in a normal distribution, skewness and 
kurtosis values were analyzed. According to Tabachnick and Fidell (2014), if the skewness and kurtosis values are between +1.5 and -1.5 , the values are considered to have a normal distribution and analyzes are performed accordingly.

Table 2. Measures of Central Tendency of Variables and Kurtosis-Skewness Coefficients

\begin{tabular}{|c|c|c|c|c|c|c|c|}
\hline & $\begin{array}{l}\text { Arithmetic } \\
\text { Mean }\end{array}$ & Mediar & Mode & $\begin{array}{l}\text { Coefficient } \\
\text { Skewness }\end{array}$ & $\begin{array}{l}\text { of Standard } \\
\text { Error } \\
\text { Skewness }\end{array}$ & 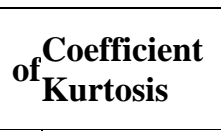 & $\begin{array}{l}\text { of Standard } \\
\text { Error } \\
\text { Kurtosis }\end{array}$ \\
\hline $\begin{array}{l}\text { Organizational } \\
\text { Justice }\end{array}$ & 4,00 & 4,00 & 5,00 &,- 63 & ,13 & , 00 &, 25 \\
\hline $\begin{array}{l}\text { Distributive } \\
\text { Justice }\end{array}$ & 3,96 & 4,00 & 5,00 &,- 79 & ,13 &, 52 &, 25 \\
\hline Procedural Justice & e3,91 & 4,00 & 5,00 &,- 62 &, 13 &,- 09 & ,25 \\
\hline $\begin{array}{l}\text { Interactional } \\
\text { Justice }\end{array}$ & 4,24 & 4,25 & 5,00 &,- 97 &, 13 & 84 & 25 \\
\hline $\begin{array}{l}\text { Organizational } \\
\text { Climate }\end{array}$ & 2,49 & 2,49 & 2,49 & ,40 &, 13 & ,99 & ,25 \\
\hline $\begin{array}{l}\text { Supportive } \\
\text { Principal }\end{array}$ & 2,98 & 3,00 & 3,00 &,- 42 & ,13 &,- 57 & , 25 \\
\hline $\begin{array}{l}\text { Peremptory } \\
\text { Principal }\end{array}$ & 2,21 & 2,29 & 2,43 &, 15 & ,13 &,- 54 &, 25 \\
\hline $\begin{array}{l}\text { Restrictive } \\
\text { Principal }\end{array}$ & 1,98 & 1,80 & 1,60 & ,68 & ,13 &, 14 & ,25 \\
\hline Sincere Teacher & 2,49 & 2,43 & 2,14 &, 15 & ,13 &,- 21 &, 25 \\
\hline $\begin{array}{l}\text { Collaborative } \\
\text { Teacher }\end{array}$ & 2,91 & 2,93 & 3,00 &,- 35 & 13 &, 44 &, 25 \\
\hline Reckless Teacher & 1,76 & 1,75 & 1,00 &, 72 &, 13 &,- 14 &, 25 \\
\hline
\end{tabular}

When Table 2, which includes the measures of central tendency and kurtosis - skewness values of the variables, is examined, it is seen that the kurtosis and skewness values of the variables are between -1 and +1 . Accordingly, it was seen that the variables showed a normal distribution, and it was appropriate to perform parametric tests in the analysis of the data.

The relationships between organizational justice, sub-dimensions of organizational justice, distributive justice, procedural justice, interactional justice, and school climate variables were analyzed by calculating the Pearson correlation coefficient. In correlation analyzes, a correlation coefficient of , $10 \leq \mathrm{r}<, 30$ indicates that there is a low level of correlation, , $30 \leq \mathrm{r}$ $<, 50$ indicates that the relationship is moderate, and $r \geq, 50$ indicates that there is a high level of relationship (Field, 2013).

\section{Findings}

In order to reveal the relationship between organizational justice and its subdimensions and school climate, Pearson correlation coefficients were calculated, and the findings are shown in Table 2.

Table 3. Pearson's Correlation Analysis Results

\begin{tabular}{lllllllllllll}
\hline & $\mathbf{1}$ & $\mathbf{2}$ & $\mathbf{3}$ & $\mathbf{4}$ & $\mathbf{5}$ & $\mathbf{6}$ & $\mathbf{7}$ & $\mathbf{8}$ & $\mathbf{9}$ & $\mathbf{1 0}$ \\
\hline $\begin{array}{l}\text { 1-Organizational } \\
\text { Justice }\end{array}$ & & & & & & & & & & & & \\
\hline
\end{tabular}




\begin{tabular}{|c|c|c|c|c|c|c|c|c|c|c|}
\hline $\begin{array}{l}\text { 2-Distributive } \\
\text { Justice }\end{array}$ &, $922^{* *}$ & & & & & & & & & \\
\hline 3-Procedural Justice &, $962^{* *}$ &, $812^{* *}$ & & & & & & & & \\
\hline $\begin{array}{l}\text { 4-Interactional } \\
\text { Justice }\end{array}$ &, $865^{* *}$ &, $738^{* * *}$ &, $773^{* * *}$ & & & & & & & \\
\hline 5-School Climate &, $446^{* *}$ &, $407^{* *}$ &, $432^{* *}$ &, $387^{* *}$ & & & & & & \\
\hline $\begin{array}{l}\text { 6-Supportive } \\
\text { Principal }\end{array}$ &, $766^{* *}$ &, $688^{* * *}$ &, $732^{* * *}$ &, $708^{* *}$ &, $581^{* *}$ & & & & & \\
\hline $\begin{array}{l}\text { 7-Peremptory } \\
\text { Principal }\end{array}$ &,$- 102^{*}$ &,- 083 &,- 075 &,$- 168^{* *}$ &, $398^{* *}$ &,$- 178^{* *}$ & & & & \\
\hline $\begin{array}{l}\text { 8-Restrictive } \\
\text { Principal }\end{array}$ &,$- 214^{* *}$ &,$- 198^{* *}$ &,$- 189^{* *}$ &,$- 227^{* *}$ &, $428^{* *}$ &,$- 174^{* *}$ &, $382^{* *}$ & & & \\
\hline 9-Sincere Teacher &, $240^{* *}$ &, $218^{* *}$ &, $222^{* *}$ &, $237^{* *}$ &, $642^{* *}$ &, $309^{* *}$ &,- 072 & ,068 & & \\
\hline $\begin{array}{l}\text { 10-Collaborative } \\
\text { Teacher }\end{array}$ &, $465^{* *}$ &, $435^{* * *}$ &, $425^{* *}$ &, $448^{* *}$ &, $623^{* *}$ &, $482^{* * *}$ & ,002 &,- 027 &, $457^{* * *}$ & \\
\hline $\begin{array}{l}\text { 11-Reckless } \\
\text { Teacher }\end{array}$ &,$- 300^{* *}$ &,$- 275^{* *}$ &,$- 282^{* *}$ &,$- 278^{* *}$ &, $200^{* *}$ &,$- 289^{* *}$ &, $198^{* *}$ &, $469^{* * *}$ &,- 001 &,$- 213^{* *}$ \\
\hline
\end{tabular}

$* * \mathrm{p}<, 01$

When Table 3 is examined, it is seen that there is a positive, moderate and significant relationship between organizational justice and school climate $(r=, 45, p<, 01)$. There is a positive, moderate, and significant relationship between school climate and distributive justice $(\mathrm{r}=, 41, \mathrm{p}<, 01)$, procedural justice $(\mathrm{r}=, 43, \mathrm{p}<, 01)$, and interactional justice $(\mathrm{r}=, 39, \mathrm{p}<, 01)$.

When Table 3 is examined, there is a high level of positive correlation between the distributive justice sub-dimension and the supportive principal sub-dimension $(r=, 69, p<, 01)$. The relationship between the distributive justice sub-dimension, the restrictive principal subdimension $(r=-, 20, p<, 01)$ and the reckless teacher sub-dimension $(r=-, 28, p<, 01)$ is negative, significant, and low. The relationship between the distributive justice sub-dimension and the sincere teacher sub-dimension $(\mathrm{r}=, 22, \mathrm{p}<, 01)$ is positive, significant, and low. The relationship between the procedural justice sub-dimension and the supportive principal subdimension $(\mathrm{r}=, 73, \mathrm{p}<, 01)$ is high, positive and significant. It is seen that the relationship between the procedural justice sub-dimension, the restrictive principal sub-dimension $(\mathrm{r}=-$ $, 19, \mathrm{p}<, 01)$ and the reckless teacher sub-dimension are $(\mathrm{r}=-, 28, \mathrm{p}<, 01)$ negative, low and significant. While the relationship between the procedural justice sub-dimension and the sincere teacher sub-dimension $(\mathrm{r}=, 22, \mathrm{p}<, 01)$ is positive, low and significant, the relationship between the collaborative teacher sub-dimension $(\mathrm{r}=, 43, \mathrm{p}<, 01)$ is positive, moderate and significant. The relationship between the interactional justice sub-dimension and the supportive principal sub-dimension $(\mathrm{r}=, 71, \mathrm{p}<, 01)$ is high, positive, and significant. The relationship between the interactional justice sub-dimension and the peremptory principal sub-dimension $(\mathrm{r}=-, 17, \mathrm{p}<, 01)$, the restrictive principal sub-dimension $(\mathrm{r}=, 23, \mathrm{p}<, 01)$ and the reckless teacher sub-dimension $(r=-, 28, p<, 01)$ is negative, significant and low.

When looking at the relationship between organizational justice and sub-dimensions of school climate, it is seen that there is a positive, high-level significant relationship between organizational justice and the supportive principal sub-dimension $(r=, 77, p<, 01)$ and the collaborative teacher sub-dimension $(r=, 47, p<, 01)$. There is a negative, low-level significant relationship between organizational justice and the restrictive principal sub-dimension ( $\mathrm{r}=-$ $, 21, \mathrm{p}<, 01)$. It is seen that the relationship between organizational justice and the peremptory principal sub-dimension ( $\mathrm{r}=-, 10, \mathrm{p}>, 01)$ is negative, low and not significant. While there is a positive, low-level, significant relationship between organizational justice and sincere teacher 
sub-dimension $(\mathrm{r}=, 24, \mathrm{p}<, 01)$, it is seen that there is a negative, moderate, significant relationship between organizational justice and reckless teacher sub-dimension $(\mathrm{r}=-, 30$, $\mathrm{p}<, 01)$. The results of the simple regression analysis performed regarding the prediction of organizational justice and its sub-dimensions for the school climate variable are given in Table 4.

Table 4. Simple Regression Analysis Results Related to the Prediction of Organizational Justice on School Climate

\begin{tabular}{lllllllll}
\hline \multicolumn{1}{c}{ Predictive Variable B } & ShB & $\boldsymbol{\beta}$ & t & p & r \\
\hline \multicolumn{1}{c}{ Constant } & 1,721 &, 082 & & & 21,089 &, 000 & & \\
Organizational Justice &, 192 &, 020 & &, 446 & 9,567 &, 000 &, 446 \\
\hline $\mathrm{R}=0,446$ & $\mathrm{R}^{2}=0,199$ & & & & & & \\
$\mathrm{~F}(7,529)=91,522$ & $\mathrm{p}=0,000$ & & & & & & \\
\hline
\end{tabular}

When the correlation coefficient between organizational justice, which is the predictor variable, and the school climate, which is the predicted variable, is examined in Table 4, it is seen that there is a moderately positive relationship $(\mathrm{R}=0,446)$ between the perception of organizational justice and school climate. When the analysis results are examined, organizational justice perception is a significant predictor of school climate $(\mathrm{R}=0,446$, $\left.\mathrm{R}^{2}=0,199, \mathrm{~F}(7,529)=91,522, \mathrm{p}<0,01\right)$. Organizational justice perception explains nearly $20 \%$ of the school climate variance.

Table 5. Multiple Linear Regression Analysis Results Related to the Sub-Dimensions of Organizational Justice Predicting the School Climate

\begin{tabular}{llllllll}
\hline \multicolumn{1}{c}{$\begin{array}{c}\text { Predictive } \\
\text { Variable }\end{array}$} & $\mathbf{B}$ & $\mathbf{S h B}$ & $\boldsymbol{\beta}$ & $\mathbf{t}$ & $\mathbf{p}$ & Paired-r & Partial r \\
\hline Constant & 1,721 &, 090 & & 19,224 &, 000 & & \\
Distributive Justice &, 052 &, 033 &, 134 & 1,591 &, 113 &, 407 &, 083 \\
Procedural Justice &, 098 &, 035 &, 250 & 2,795 &, 005 &, 432 &, 145 \\
Interactional Justice &, 042 &, 034 &, 096 & 1,243 &, 215 &, 387 &, 065 \\
\hline $\begin{array}{l}\mathrm{R}=0,446 \\
\mathrm{~F}(2,511)=30,370\end{array}$ & $\begin{array}{l}\mathrm{R}^{2}=0,199 \\
\mathrm{p}=0,000\end{array}$ & & & & & & \\
\hline
\end{tabular}

When Table 5 is examined, it is seen that all sub-dimensions of organizational justice are predictors of school climate $(\mathrm{R}=0,446, \mathrm{R} 2=0,199, \mathrm{p}<, 01)$. The three sub-dimensions of organizational justice, distributive justice, procedural justice and interactional justice, explain $20 \%$ of the variance of the school climate. The order of importance of the sub-dimensions of organizational justice, which is the predictor variable, in explaining the school climate is procedural justice $(\beta=0,250)$, distributive justice $(\beta=0,134)$ and interactional justice $(\beta=0,096)$. When the values regarding the significance of the regression coefficients are examined, it is seen that the procedural justice sub-dimension of organizational justice $(\mathrm{p}<, 05)$ significantly explains the school climate.

When the binary correlation and partial correlation between the sub-dimensions of organizational justice, which is the predictor variable, and the school climate, which is the predicted variable, are examined, it is seen that there is a moderate positive relationship $(r=0,41)$ between the distributive justice sub-dimension and the school climate. When the 
effects of the other two sub-dimensions are controlled, it is seen that this relationship decreases even more $(\mathrm{r}=0,08)$. It is seen that there is a moderately positive correlation $(\mathrm{r}=0,43)$ between the procedural justice sub-dimension and the school climate. When the effects of the other two dimensions are controlled, it is seen that this relationship decreases even more $(\mathrm{r}=0,15)$. It is seen that there is a moderately positive relationship $(\mathrm{r}=0,39)$ between the interactional justice sub-dimension and the school climate. When the effects of the other two dimensions are controlled, it is seen that this relationship decreases even more $(r=0,07)$.

Table 6. Regression Analysis Results Related to the Organizational Justice Predicting Principal Behaviors Sub-Dimensions of the School Climate

\begin{tabular}{|c|c|c|c|c|c|c|c|c|c|c|c|c|}
\hline \multirow{2}{*}{ 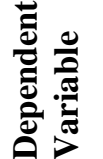 } & \multicolumn{4}{|c|}{ Supportive Principal } & \multicolumn{4}{|c|}{ Peremptory Principal } & \multicolumn{4}{|c|}{ Restrictive Principal } \\
\hline & B & $\boldsymbol{\beta}$ & $\mathbf{t}$ & $\mathbf{p}$ & B & $\boldsymbol{\beta}$ & $\mathbf{t}$ & $\mathbf{p}$ & B & $\boldsymbol{\beta}$ & $\mathbf{t}$ & $\mathbf{p}$ \\
\hline
\end{tabular}

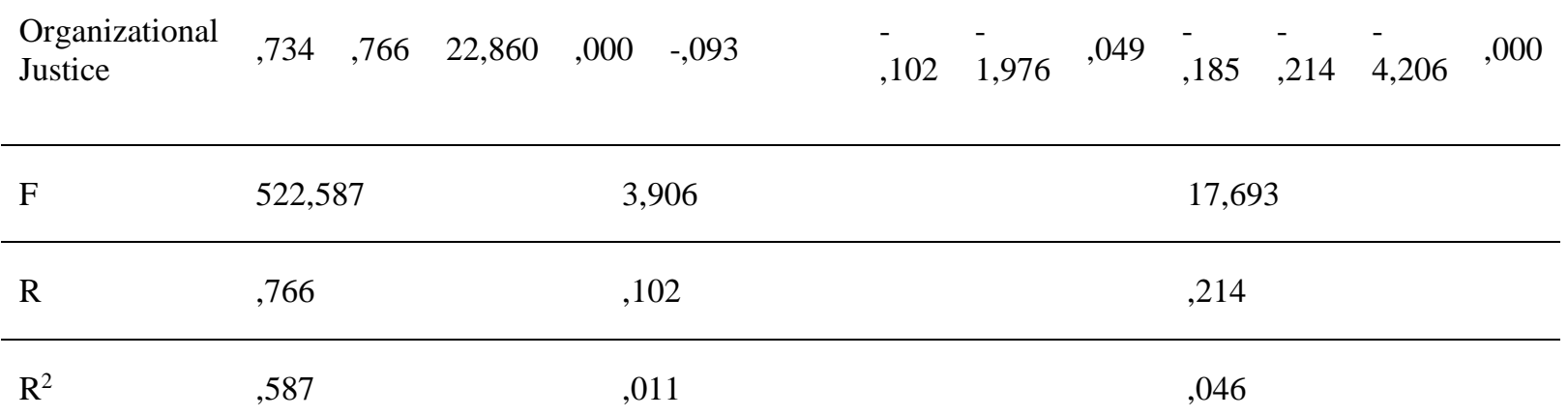

It is seen that the organizational justice variable is a significant predictor of the supportive principal $\left(\mathrm{R}=, 766, \mathrm{R}^{2}=, 587, \mathrm{p}<, 01\right)$ and the restrictive principal $(\mathrm{R}=, 214, \mathrm{R} 2=, 046, \mathrm{p}<, 01)$ variables. It is seen that the organizational justice variable explains nearly $59 \%$ of the variance for the supportive principal sub-dimension, $1 \%$ of the variance for the peremptory principal sub-dimension, and nearly $5 \%$ of the variance for the restrictive principal subdimension.

Table 7. Regression Analysis Results Related to the Organizational Justice Predicting Teacher Behaviors Sub-Dimensions of the School Climate

\begin{tabular}{|c|c|c|c|c|c|c|c|c|c|c|c|c|}
\hline \multirow{2}{*}{ 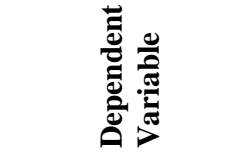 } & \multicolumn{4}{|c|}{ Sincere Teacher } & \multicolumn{4}{|c|}{ Collaborative Teacher } & \multicolumn{4}{|c|}{ Reckless Teacher } \\
\hline & B & $\beta$ & $\mathbf{t}$ & $\mathbf{p}$ & B & $\beta$ & $\mathbf{t}$ & $\mathbf{p}$ & B & $\beta$ & $\mathbf{t}$ & $\mathbf{p}$ \\
\hline $\begin{array}{l}\text { Organizational } \\
\text { Justice }\end{array}$ &, 217 &, 240 & 4,751 &, 000 &, 282 &, 465 & 10,068 &, 000 &,- 260 &,- 300 & $-6,022$ &, 000 \\
\hline $\mathrm{F}$ & \multicolumn{4}{|c|}{22,567} & \multicolumn{4}{|c|}{101,368} & \multicolumn{4}{|c|}{36,265} \\
\hline $\mathrm{R}$ & \multicolumn{4}{|c|}{240} & \multicolumn{4}{|c|}{465} & \multicolumn{4}{|c|}{300} \\
\hline $\mathrm{R}^{2}$ & \multicolumn{4}{|l|}{, 058} & \multicolumn{4}{|c|}{,216 } & \multicolumn{4}{|l|}{,090 } \\
\hline
\end{tabular}

It is seen that the organizational justice variable is a significant predictor of the sincere teacher $\left(\mathrm{R}=, 240, \mathrm{R}^{2}=, 058, \mathrm{p}<, 01\right)$, collaborative teacher $(\mathrm{R}=, 465, \mathrm{R} 2=, 216, \mathrm{p}<, 01)$ and reckless teacher $\left(R=, 300, R^{2}=, 090, p<, 01\right)$ variables. It is seen that the organizational justice variable explains nearly $6 \%$ of the variance for the sincere teacher sub-dimension, nearly $22 \%$ of the variance for the collaborative teacher sub-dimension, and $9 \%$ of the variance for the reckless teacher sub-dimension. 


\section{Discussion}

As a result of the research, it was found that there is a positive, moderately significant relationship between organizational justice and school climate, and that organizational justice significantly predicts the school climate. A positive, moderately significant relationship was found between the "distributive justice", "procedural justice", and "interactional justice" subdimensions of organizational justice and the school climate. The order of importance of the sub-dimensions of organizational justice in explaining the school climate was found as procedural justice, distributive justice, and interactional justice.

In the study, it was concluded that organizational justice significantly predicted the supportive principal and restrictive principal variables, which are sub-dimensions of school climate related to principal behavior and had no significant relationship with the peremptory principal variable. It is seen that perceived organizational justice positively affects the supportive principal sub-dimension of the school climate, has a negative effect on restrictive principal behavior, and has no effect on the peremptory principal behavior. From this point of view, it can be said that as teachers' perceptions of justice towards their schools increase, they find school administrators more supportive. In the study conducted by Çekiç (2018), there was a moderate positive relationship between the perception of organizational justice and the supportive principal and peremptory principal behaviors, while there was no relationship between the perception of organizational justice and the restrictive principal behavior. According to Achmadi (2016), school administrators' fair approach to teachers has a significant effect on the climate in the school. In the research conducted by Huang et al. (2019) with employees of the ecology industry, a positive significant relationship was found between organizational justice and organizational climate, and it was suggested that the principals should adopt a leadership approach taking this into account. A similar result can be seen in the study conducted by Çekiç (2018) in primary schools. According to this study, as the level of organizational justice in schools increases, the perception towards school climate increases positively. In the research conducted by Raj et al. (2016) in telecommunication organizations, it was found that there is a strong relationship between organizational justice, organizational climate, and organizational citizenship behavior. In addition, it has been concluded that organizational justice has a significant effect on the perception of organizational climate and promoting organizational citizenship behavior.

Considering the sub-dimensions of the school climate related to teacher behavior, it was found that while the perception of organizational justice positively affected cooperative teacher behavior and sincere teacher behavior, it had a negative effect on reckless teacher behavior. In the study conducted by Dipaola and Guy (2009), it was also concluded that cooperative and sincere teacher behaviors increased in schools where teachers perceived that they were treated fairly. When the research results are evaluated in the context of all subdimensions of the school climate, it is seen that the effect of organizational justice perception on the supportive principal sub-dimension, which is one of the sub-dimensions of the school climate, is seen to be the most.

\section{Conclusion}

According to these findings obtained as a result of the research, it has been observed that the relationship between organizational justice and school climate is at a moderate level. Organizational justice is a significant predictor of school climate. Each of the distributive justice, procedural justice and interactional justice sub-dimensions of organizational justice has a moderately positive relationship with school climate. The order of importance of the 
sub-dimensions of organizational justice in explaining the school climate was also found as procedural justice, distributive justice and interactional justice. In addition, it was concluded in the study that organizational justice significantly predicted supportive principal and restrictive principal variables, which are sub-dimensions of school climate related to school principal behaviors, and that there was no significant relationship between it and the imperative principal variable. It is seen that perceived organizational justice has a positive effect on the supportive principal sub-dimension of the school climate, has a negative effect on the restrictive principal behavior, and has no effect on the peremptory principal behavior. Some of the positive or negative perceptions about the school climate can be explained by organizational justice. In other words, the school climate perceptions of the teachers, who think that they are treated fairly, who find the practices in the school fair, who are included in decision-making processes, and who think that their wishes and needs are given importance, will be positively affected. It can be said that teachers' perceptions of organizational justice and school climate affect their performance, their communication within the school, their interactions, and the quality of education. Based on these findings, it can be said that the perception of practices as fair by teachers in defining responsibilities, distributing rewards, allocating resources at school, in the process of carrying out procedures, in communication and interaction affects teachers' attitudes towards school climate.

\section{Recommendations}

According to the results of the research, it is seen that the perception of organizational justice predicts the school climate. Based on this result, school administrators who want to establish more equitable educational institutions can act impartially and act fairly in the distribution of the awards. At the beginning of the year, he can act in a balanced way in sharing the lessons among the teachers. Care can be taken to act impartially and fairly in assigning various extracurricular activity tasks to teachers and in defining and distributing responsibilities. Also, school administrators can objectively consult their opinions and collect information from them on issues that concern teachers, without making any distinction between them. The decisions taken can be shared with the teachers clearly and understandably and, if requested, with their reasons. School administrators may take care to be impartial and consistent with all teachers in applying legislation provisions such as laws, regulations, and circulars.

School administrators can make teachers feel that they value teachers with their behavior and words, and they can take care of teachers' happiness. In schools, action can be taken by considering the expectations and needs of teachers. Both school administrators and teachers can show more supportive and sharing behaviors among themselves. School administrators can apply questionnaires measuring the school climate from time to time in order to observe how the atmosphere in the school is perceived by the teachers and take the necessary measures according to the results of these questionnaires. In order to increase communication and interaction in the school, various activities that teachers can participate in with their families, training that can contribute to professional development, social activities and meetings can be organized both inside and outside the school.

In summary, it is important to design fair organizations in order for teachers to perceive the climate in their schools more positively, because working in schools that teachers do not perceive as fair and have a negative climate will negatively affect their performance and decrease their motivation. Therefore, appropriate policies can be developed by policymakers (Ministry of National Education, Provincial Directorate of National Education, etc.) to 
increase the level of justice in schools. Theoretical and practical training on organizational justice and climate can be planned for school administrators and they can be interacted with school administrators who can demonstrate good examples in this sense.

\section{Limitations}

This research, like many studies, is limited to the determined population and sample. Therefore, a similar study can be conducted throughout Turkey in order to obtain more generalizing results. Similar studies can be conducted in different school types or different education levels, on the basis of a certain branch, in other cities, regions or countries to test the results in different populations and samples. In addition to this, since this research is a quantitative study conducted with the relational survey model, similar studies with mixed patterns can be designed in which qualitative data collection techniques are also used in order to reveal data diversity. This study focuses on the relationship between organizational justice and sub-dimensions of organizational justice and school climate, and different studies can be conducted to test the effects of different variables on the school climate, which are considered to affect teachers' perception levels of school climate.

\section{Acknowledgements}

During the writing process of the study titled "The Relationship Between Secondary School Teachers' Perception of Organizational Justice and School Climate", scientific, ethical and quotation rules were followed, no alteration was made on the collected data and this study was not sent to any other academic publication environment for evaluation. The data of the research were collected in the 20202021 academic year.

This article has been produced from Mustafa KEMER's Master's thesis titled "The Relationship Between Secondary School Teachers' Perception of Organizational Justice and School Climate" supervised by Prof. Dr. Soner POLAT.

\section{References}

Achmadi, A. (2016). The effect of leadership behavior, justice and organizational climate on dignity behavior. European Journal of Business and Management, 8(8), 115-120.

Açıkgöz, A. (2009). Okul yöneticilerinin çatışma yönetim stilleri ile ögretmenlerin örgütsel adalet algist arasındaki ilişki [Conflict management styles of school, administrators and the relationship between organizational justice]. (Unpublished master's thesis). Abant Izzet Baysal University, Institute of Social Sciences, Bolu.

Alazmi, A. A. \& Alenezi, A. S. (2020). Exploring the mediating role of trust in principal on the relationship between organizational justice and teacher commitment in Kuwait. International Journal of Leadership in Education, 1-17. https://doi.org/10.1080/13603124.2020.1832705

Altınkurt, Y. \& Yılmaz, K. (2010). Değerlere göre yönetim ve örgütsel adalet ilişkisinin ortaöğretim okulu öğretmenlerinin algılarına göre incelenmesi [Examining the relationship between management by values and organizational justice by secondary school teachers' perceptions]. Kuram ve Uygulamada Eğitim Yönetimi [Educational Administration: Theory and Practice ], 4(4), 463-485.

Aquino, K. (1995). Relationships among pay inequity, perceptions of procedural justice, and organizational citizenship. Employee Responsibilities and Rights Journal, 8(1), 21-33. https://doi.org/10.1007/BF02621253

Balc1, A. (2001). Örgütsel gelişme: Kuram ve uygulama [Organizational development: Theory and practice]. Ankara: Pegem Academy. 
Balı, A. Ş. (2001). Çok kültürlülük ve sosyal adalet: "Öteki" ile barış içinde birlikte yaşamak [Multiculturalism and social justice: To live together in peace with the "Other"]. Konya: Çizgi Bookstore.

Barling, J. \& Phillips, M. (1993). Interactional, formal, and distributive justice in the workplace: An exploratory study. The Journal of Psychology, 127(6), 649-656. https://doi.org/10.1080/00223980.1993.9914904

Beugre, C. D. (1998). Managing fairness in organizations. London: Greenwood.

Büyüköztürk, Ş. (2014). Sosyal bilimler için veri analizi el kitabı [Data analysis handbook for social sciences]. Ankara: Pegem Academy.

Cansoy, R. \& Polatcan, M. (2018). Türkiye'de okullarda örgütsel adalet araştırmaları: Ampirik araştırmalara bir bakış [Research on organizational justice in Turkish schools: a review of literature]. Turkish Studies, 13(4), 163-184. https://doi.org/10.7827/TurkishStudies.12912

Cohen, A. \& Keren, D. (2010). Does climate matter? An examination of the relationship between organizational climate and OCB among Israeli teachers. The Service Industries Journal, 30(2), 247-263. https://doi.org/10.1080/02642060802120158

Cohen-Charash, Y. \& Spector, P. E. (2001). The role of justice in organizations: A metaanalysis. Organizational Behavior and Human Decision Processes, 86(2), 278-321. https://doi.org/10.1006/obhd.2001.2958

Cropanzano, R., Bowen, D. E. \& Gilliland, S. W. (2007). The management of organizational justice. Academy of Management Perspectives, 21(4), 34-48. https://doi.org/10.5465/amp.2007.27895338

Cüce, H., Güney, S. \& Tayfur, Ö. (2013). Örgütsel adalet algılarının örgütsel özdeşleşme üzerindeki etkisini belirlemeye yönelik bir araştırma [A Study investigating the effect of organizational justice perceptions on organizational identification]. Hacettepe Üniversitesi İktisadi ve İdari Bilimler Fakültesi Dergisi [Hacettepe University Journal of Economics and Administrative Sciences], 31(1), 1-30. https://doi.org/10.17065/huniibf.103652

Çekiç, E. (2018). Illköğretim okullarındaki ögretmenlerin görüşlerine göre örgütsel adalet ve örgütsel iklim arasındaki ilişki (Edirne ili örneği) [Relationships between organizational justice and organizational climate according to primary school teacher (Edirne province sample)]. (Unpublished master's thesis). Trakya University, Institute of Social Sciences, Edirne.

Çetin, S. \& Polat, S. (2021). Ortaokul öğretmenlerinin örgütsel adalet algı düzeyleri ile örgütsel mutluluk düzeyleri arasındaki ilişki [The relationship between secondary school teachers' organizational justice perception levels and organizational happiness levels]. Manas Sosyal Araştırmalar Dergisi [MANAS Journal of Social Studies], 10(1), 171-182. https://doi.org/10.33206/mjss.800081

Demirbolat, A. O. (1999). Yönetici ve empatik yaklaşım [Administrators and the empathetic approach]. Eğitim ve Bilim [Education and Science], 24(114), 82-85.

Demirel, Y. \& Seçkin, Z. (2011). Örgütsel adaletin bilgi paylaşımı üzerine etkisi: İlaç sektörü çalışanlarına yönelik bir araştırma [The impact of organizational justice on knowledge sharing: research on drug industry employees]. Bilig, 56, 99-119.

Demirtaş, H. \& Güneş, H. (2002). Eğitim yönetimi ve denetimi sözlüğü [Dictionary of educational management and supervision]. Ankara: Anı Publishing.

Dipaola, M. \& Guy, S. (2009). The impact of organizational justice on climate and trust in high schools. Journal of School Leadership, 19(4), 382-405. https://doi.org/10.1177/105268460901900401

Field, A. (2013). Discovering statistics using IBM SPSS statistics. Thousand Oaks: Sage Publications. 
Fraenkel, J. R., Wallen, N. E. \& Hyun, H. H. (2012). How to design and evaluate research in education (8th ed.). Boston: McGraw Hill.

Greenberg, J. (1987). A taxonomy of organizational justice theories. Academy of Management Review, 12(1), 9-22. https://doi.org/10.5465/amr.1987.4306437

Greenberg, J. (1990). Organizational justice: Yesterday, today, and tomorrow. Journal of Management, 16(2), 399-432. https://doi.org/10.1177/014920639001600208

Greenberg, J. (1996). The quest for justice on the job: essays and experiments. Thousand Oaks: Sage Publications.

Greenberg, J. (2003). Creating unfairness by mandating fair procedures: The hidden hazards of a pay-for-performance plan. Human Resource Management Review, 13(1), 41-57. https://doi.org/10.1016/S1053-4822(02)00098-0

Halpin, A. W. \& Croft, D. B. (1963). The organizational climate of schools. Chicago: Midwest Administration Center.

Hoy, W. K. \& Miskel, C. G. (2010). Eğitim yönetimi: Teori, araştırma ve uygulama (S. Turan, Trans.) [Educational administration: Theory, research and practice]. Ankara: Nobel Academic.

Hoy, W. K. \& Tarter, C. J. (2004). Organizational justice in schools: No justice without trust. International Journal of Educational Management, 8(4), 250-259. https://doi.org/10.1108/09513540410538831

Hoy, W. K., Tarter, C. J. \& Kottkamp, R. B. (1991). Open schools, healthy schools: Measuring organizational climate. Newbury Park, CA: Corwin.

Huang, L. C., Gao, M. \& Hsu, P. F. (2019). Effects of Organizational Justice on Organizational Climate and Organizational Performance in Ecology Industry. Ekoloji, 28(107), 237-241.

Irak, D. U. (2004). Örgütsel adalet: Ortaya çıkışı, kuramsal yaklaşımlar ve bugünkü durumu [Organizational justice: Appearance, theoretical approaches and current state]. Türk Psikoloji Yazılarl [Turkish Psychological Articles], 7(13), 25-43.

İçerli, L. (2010). Örgütsel adalet: Kuramsal bir yaklaşım [Organizational justice: A theorical approach]. Girişimcilik ve Kalkınma Dergisi [Journal of Entrepreneurship and Development], 5(1), 67-92.

İşcan, Ö. F. \& Naktiyok, A. (2004). Çalışanların örgütsel bağdaşımlarının belirleyicileri olarak örgütsel bağlılık ve örgütsel adalet algıları [Perceptions of employees about organizational commitment and justice as determinants of their organizational coherence]. Ankara Üniversitesi Siyasal Bilgiler Fakültesi Dergisi [Ankara University Journal of the Faculty of Political Science], 59(1), 181-201. https://doi.org/10.1501/SBFder_0000001477

Katsantonis, I. G. (2020). Investigation of the impact of school climate and teachers' selfefficacy on job satisfaction: A croos-cultural approach. European Journal of Investigation in Health, Psychology and Education, 10(1), 119-133. https://doi.org/10.3390/ejihpe10010011

Moorman, R. H. (1991). Relationship between organizational justice and organizational citizenship behaviors: Do fairness perceptions influence employee citizenship? Journal of Applied Psychology, 76(6), 845-855. https://doi.org/10.1037/00219010.76.6.845

Özkalp, E. \& Kırel, Ç. (2013). Örgütsel davranıs [Organizational behavior] (6th ed.). Bursa: Ekin Publishing.

Polat, S. (2007). Ortaöğretim öğretmenlerinin örgütsel adalet algılart, örgütsel güven düzeyleri ile örgütsel vatandaşlı davranışları arasındaki ilişki [Relation between organizational justice perceptions, organizational trust levels and organizational 
citizenship behaviors of secondary education teachers]. (Unpublished doctoral dissertation). Kocaeli University, Institute of Social Sciences, Kocaeli.

Raj, N., Subramani, N., Jan, N. A. \& Mahesan, S. S. (2016). Examining the interrelationship among organizational justice (oj), organizational climate (oc) and organizational citizenship behavior (ocb) with respect to telecommunication industries in Chennai. International Journal of Economic Research, 13(4), 1945-1961.

Sweetland, S. R. \& Hoy, W. K. (2000). School characteristics and educational outcomes: Toward an organizational model of student achievement in middle schools. Educational Administration Quarterly, 36(5), 703-729. https://doi.org/10.1177/00131610021969173

Şişman, M. (2011). Öğretim liderliği [Instructional leadership]. Ankara: Pegem Academy.

Tabachnick, B. G. \& Fidell, L. S. (2014). Using multivariate statistics. Essex: Pearson.

Tutar, H. \& Altınöz, M. (2010). Örgütsel iklimin iş gören performansı üzerine etkisi: OSTİM imalat işletmeleri çalışanları üzerine bir araştırma [The effect of organizational climate on employee performance: A study on the employees of Ostim manufacturing enterprises]. Ankara Üniversitesi Siyasal Bilgiler Fakültesi Dergisi [Ankara University Journal of the Faculty of Political Science], 195-218. https://doi.org/10.1501/SBFder_0000002162

Usmani, S. \& Jamal, S. (2013). Impact of distributive justice, procedural justice, interactional justice, temporal justice, spatial justice on job satisfaction of banking employees. Review of Integrative Business and Economics Research, 2(1), 351-383.

Welsh, W. N. (2000). The effects of school climate on school disorder. The Annals of the American Academy of Political and Social Science, 567(1), 88-107. https://doi.org/10.1177/000271620056700107

Yahyagil, M. Y. (2006). The fit between the concepts of organizational culture and climate. Journal of Organizational Culture, Communications and Conflict, 10(2), 77-104.

Yazıcıŏlu, Y. \& Erdoğan, S. (2004). SPSS uygulamalı bilimsel araştırma yöntemleri [SPSS applied scientific research methods]. Ankara: Detay Publishing.

Yılmaz, K. \& Altınkurt, Y. (2013). Örgütsel iklim ölçeğinin Türkçeye uyarlanması: Geçerlik ve güvenirlik çalışması [Adaptation of organizational climate scale into Turkish: The validity and reliability study]. Trakya Üniversitesi Ë̆itim Fakültesi Dergisi [Trakya University Journal of Education], 3(1), 1-11.

Yürür, Ş. (2008). Örgütsel adalet ile iş tatmini ve çalışanların bireysel özellikleri arasındaki ilişkilerin analizine yönelik bir araştırma [A study of analyzing the relationships between organizational justice and job satisfaction and personal characteristics of employees]. Süleyman Demirel Üniversitesi İktisadi ve İdari Bilimler Fakültesi Dergisi [Suleyman Demirel University The Journal of Faculty of Economics and Administrative Sciences], 13(2), 295-312. 